Vol 1. No. 3, Juli 2021 P-ISSN : 2774-8030, e-ISSN : 2774-8030

\title{
PENERAPAN STRATEGI PENINJAUAN KEMBALI DENGAN PENCOCOKAN KARTU INDEKS DALAM MENINGKATKAN HASIL BELAJAR MATEMATIKA
}

\author{
DEDE SUTISNA \\ SMP Negeri 2 Jakarta \\ e-mail: dsutisna15@gmail.com
}

\begin{abstract}
ABSTRAK
Penerapan Strategi Peninjauan Kembali dengan Pencocokan Kartu Indeks diterapakan pada Siswa Kelas IX.2 SMPN 2 Jakarta dengan tujuan untuk meningkatkan hasil belajar matematika. Hipotesis tindakan yang dirumuskan adalah "Melalui strategi peninjauan kembali dengan pencocokan kartu indeks, akan meningkatkan hasil belajar matematika pada siswa kelas IX.2 SMP Negeri 2 Jakarta". Penelitian ini dilakukan dalam dua siklus terhadap 33 orang siswa. Teknik pengumpulan data melalui observasi oleh guru dan kolaborator, dan analisis data dilakukan secara deskripsi dengan teknik persentase. Tingkat aktifitas (h) dalam proses pembelajaran, dengan katagori tinggi (jika $\mathrm{h}$ $\geq 80 \%$ ), sedang (jika $60 \leq \mathrm{h}<80$ ), dan rendah (jika $\mathrm{h}<60$ ). Sedangkan tingkat keberhasilan strategi peninjauan kembali dengan pencocokan kartu indeks, dengan katagori berhasil ( $\bar{x} \geq 73,00$ dan KTB $\geq 70 \%$ ), kurang berhasil ( $\bar{x}<73,00$ dan KTB $\geq 70 \%$ atau $\bar{x} \geq 73,00$ dan KTB $<70 \%$ ), dan tidak berhasil $(\bar{x}<73,00$ dan KTB $<70 \%)$. Hasil penelitian menyimpulkan bahwa penerapan strategi peninjauan kembali dengan pencocokan kartu indeks berhasil meningkatkan hasil belajar matematika pada siswa kelas IX.2 SMPN 2 Jakarta. Hal ini ditunjukkan dengan rata-rata hasil belajar siswa kelas IX.2 sebelum PTK, pada siklus I dan siklus II berturut-turut adalah 58,97\%, 75,64\% dan 79,19\%. Sedangkan ketuntasan belajar sebelum PTK, pada siklus I dan siklus II berturut-turut adalah $23,51 \%, 63,64 \%$ dan $75,00 \%$. Untuk meningkatkan hasil belajar matematika siswa dalam pembelajaran matematika, khususnya pada materi barisan bilangan guru dapat menggunakan strategi peninjauan kembali dengan pencocokan kartu indeks.
\end{abstract}

Kata kunci : hasil belajar matematika, peninjauan kembali, kartu indeks

\section{PENDAHULUAN}

Perkembangan informasi, ilmu pengetahuan dan teknologi mendorong perubahan kurikulum pendidikan di Indonesia. Kurikulum Tingkat Satuan Pendidikan (KTSP) telah digantikan oleh Kurikulum 2013 (K13). Dimensi sikap, pengetahuan, dan keterampilan menjadi patokan dalam menentukan standar kompetensi lulusan. Hal ini tercantum dalam Peraturan Menteri Pendidikan dan Kebudayaan Nomor 54 Tahun 2013 tentang Standar Kompetensi Lulusan Pendidikan Dasar dan Menengah. Ketiga dimensi tersebut selanjutnya dirinci pada Peraturan Menteri Pendidikan dan Kebudayaan Nomor 65 Tahun 2013 tentang Standar Proses menjadi kata kerja operasional menerima, menjalankan menghargai, menghayati dan mengamalkan (dimensi sikap) ; mengingat, memahami, menerapkan, menganalisis, dan mengevaluasi (dimensi pengetahuan); serta mengamati, menanya, mencoba, menalar, menyaji dan mencipta (dimensi keterampilan).

Sebelumnya, dalam Peraturan Menteri Pendidikan Nasional Republik Indonesia Nomor 23 Tahun 2006 tentang Standar Kompetensi Lulusan Pendidikan dinyatakan bahwa tujuan pendidikan dasar yang meliputi SD/MI/SDLB/Paket A dan SMP/MTs/SMPLB/Paket B adalah meletakkan dasar kecerdasan, pengetahuan, kepribadian, akhlak mulia, serta keterampilan untuk hidup mandiri dan mengikuti pendidikan lebih lanjut. Ketiga dasar kecerdasan tersebut sesuai dengan dimensi yang terdapat dalam Peraturan Menteri Pendidikan dan Kebudayaan Nomor 54 Tahun 2013 tentang Standar Kompetensi Lulusan Pendidikan Dasar dan Menengah yang telah disebutkan di atas. 
Selanjutnya dalam peraturan tersebut standar kompetensi lulusan (SKL) dirinci tiap mata pelajaran. Misalnya SKL mata pelajaran matematika diuraikan sebagai berikut : 1) Memahami konsep bilangan real, operasi hitung dan sifat-sifatnya(komutatif, asosiatif, distributif), barisan bilangan sederhana (barisan aritmatika dan sifat-sifatnya), serta penggunaannya dalam pemecahan masalah. 2) Memahami konsep aljabar meliputi : bentuk aljabar dan unsur-unsurnya, persamaan dan pertidaksamaan linier serta penyelesaiannya, himpunan dan operasinya, relasi, fungsi dan grafiknya, system persamaan linier dan penyelesaiannya, serta menggunakannya dalam pemecahan masalah. 3) Memahami bangun-bangun geometri, unsur-unsur, dan sifat-sifatnya, ukuran dan pengukurannya, meliputi hubungan antar garis, sudut (melukis sudut dan membagi sudut), segitiga (termasuk melukis segitiga) dan segiempat, teorema Pythagoras, lingkaran (garis singgung sekutu, lingkaran dalam dan lingkaran luar segitiga serta melukisnya), kubus, balok, prisma, limas, dan jarring-jaringnya, kesebangunan dan kongruensi, tabung, kerucut, bola, serta menggunakannya dalam pemecahan masalah. 4) Memahami konsep data, pengumpulan dan penyajian data (dengan tabel, gambar, diagram grafik), rentangan data, rerata hitung, modus, dan median, serta menerapkannya dalam pemecahan masalah. 5) Memahami konsep ruang sampel dan peluang kejadian, serta memanfaatkan dalam pemecahan masalah. 6) Memiliki sikap menghargai matematika dan kegunaannya dalam kehidupan. 7) memiliki kemampuan berpikir logis, analitis, sistematis, kritis, dan kreatif, serta mempunyai kemampuan bekerja sama.

Melihat standar kompetensi lulusan dengan materi ajar tersebut, seharusnya pembelajaran matematika merupakan kegiatan yang menantang dan menyenangkan. Ternyata dibandingkan dengan mata pelajaran lain, hasil belajar matematika di sekolah umumnya rendah. Hal ini menjadi pemandangan yang biasa. Matematika di kalangan peserta didik dianggap sebagai mata pelajaran yang menjadi momok dan sulit dipahami oleh sebagian besar dari mereka. Banyak kritikan ditujukan kepada guru matematika, antara lain rendahnya daya kreasi guru dalam pembelajaran, sehingga pembelajaran kurang bervariasi yang mengakibatkan rendahnya aktifitas siswa dalam proses pembelajaran. Hal ini juga menyebabkan pembelajaran matematika menjadi kurang bermakna.

Rendahnya hasil belajar seperi yang diuraikan di atas terlihat pada siswa yang penulis ajar. Nilai rata-rata ulangan hariannya 68,38 masih di bawah KKM yang ditetapkan yaitu 73,00.

Tabel 1 Nilai Rata-Rata Ulangan Harian Kelas IX SMP Negeri 2 Jakarta Tahun Pelajaran 2017/2018

\begin{tabular}{|c|c|c|c|c|c|c|c|}
\hline No & Kelas & $\begin{array}{c}\text { Jumlah } \\
\text { Siswa }\end{array}$ & $\begin{array}{c}\text { KD 5.1 } \\
\text { KKM = 72 }\end{array}$ & $\begin{array}{c}\mathrm{KD} 5.2 \mathrm{KKM} \\
=69\end{array}$ & $\begin{array}{c}\text { KD 5.3 } \\
\text { KKM = 69 }\end{array}$ & $\begin{array}{c}\text { KD 6.1 } \\
\text { KKM = 70 }\end{array}$ & Rata-rata \\
\hline 1 & IX.1 & 31 & 73,55 & 72,13 & 75,65 & 77,35 & 74,67 \\
\hline 2 & IX. 2 & 33 & 53,18 & 51,42 & 63,03 & 68,24 & 58,97 \\
\hline 3 & IX.3 & 32 & 74,38 & 65,84 & 70,78 & 65,52 & 69,13 \\
\hline 4 & IX.4 & 33 & 61,50 & 64,34 & 71,52 & 85.66 & 70,76 \\
\hline \multicolumn{3}{|c|}{ Rata-rata } & 65,65 & 63,43 & 73,78 & 70,24 & 68,38 \\
\hline
\end{tabular}

Sumber data diperoleh dari Daftar Nilai Matematika Semester Pertama

Dari tabel terlihat bahwa IX.2 merupakan kelas yang perolehannya paling rendah.

Adapun ketuntasan belajar dari keempat kelas tersebut juga rata-rata $(52,26 \%)$ masih di bawah harapan (KTB $\geq 70 \%$ ), seperti ditunjukkan pada tabel berikut : 
Vol 1. No. 3, Juli 2021 P-ISSN : 2774-8030, e-ISSN : 2774-8030

Tabel 2. Ketuntasan Belajar Ulangan Harian Kelas IX SMP Negeri 2 Jakarta Tahun Pelajaran 2013/2014

\begin{tabular}{|c|c|c|c|c|c|c|c|}
\hline No & Kelas & $\begin{array}{l}\text { Jumlah } \\
\text { Siswa }\end{array}$ & $\begin{array}{c}\mathrm{KD} 5.1 \\
\mathrm{KKM}= \\
72\end{array}$ & $\begin{array}{c}\text { KD } 5.2 \\
\text { KKM = } 69\end{array}$ & $\begin{array}{c}\mathrm{KD} 5.3 \\
\mathrm{KKM}= \\
69\end{array}$ & $\begin{array}{c}\text { KD } 6.1 \\
\text { KKM = } \\
70\end{array}$ & Rata-rata \\
\hline 1 & IX.1 & 31 & 54,84 & 51,61 & 96,77 & 80,65 & 70,97 \\
\hline 2 & IX.2 & 33 & 9,09 & 12,21 & 33,33 & 39,39 & 23,51 \\
\hline 3 & IX.3 & 32 & 65,63 & 46,88 & 68,75 & 37,50 & 54,69 \\
\hline 4 & IX.4 & 33 & 21,21 & 51,52 & 72,73 & 93,94 & 59,85 \\
\hline \multicolumn{3}{|c|}{ Rata-rata } & 37,69 & 40,56 & 67,90 & 62,87 & 52,26 \\
\hline
\end{tabular}

Sumber data diperoleh dari Daftar Nilai Matematika Semester Pertama

Dari tabel terlihat bahwa kelas IX.2 merupakan kelas dengan prosentase ketuntasan belajarnya paling rendah.

Suryosubroto dalam Kunandar (2008) menyatakan bahwa "Kemampuan mengelola proses belajar mengajar adalah kesanggupan atau kecakapan para guru dalam menciptakan suasana komunikasi yang edukatif antara guru dan peserta didik yang mencakup segi kognitif, afektif, dan psikomotor, sebagai upaya mempelajari sesuatu berdasarkan perencanaan sampai dengan tahap evaluasi dan tindak lanjut hingga tercapai tujuan pengajaran."

Luas dan banyaknya materi pelajaran matematika ditambah beban mata pelajaran lain sering membuat peserta didik begitu mudah lupa pada materi yang telah dipelajari ditambah lagi rendahnya aktivitas siswa dalam proses pembelajaran,. Sedangkan untuk mengulang materi di rumah dari tiap mata pelajaran, harus menyita banyak waktu sementara masa remaja mereka juga tidak boleh hilang.

Seorang guru yang berhasil adalah guru yang tidak hanya mampu mentransfer informasi kepada anak-anak didiknya. Lebih dari itu, seorang guru akan disebut berhasil apabila mereka mampu membuka peluang bagi siswa-siswanya untuk meraih keberhasilannya sendiri. Dengan kata lain, keberhasilan dalam proses belajar mengajar tidaklah semata hanya ditentukan oleh kemampuan guru dalam menyampaikan materi, melainkan juga didorong oleh kemampuan guru dalam mengajak anak-anak didiknya untuk terlibat aktif di kelas. (Isnawati, 2010)

Lebih lanjut Isnawati (2010), menyatakan bahwa salah satu cara memotivasi dan mengaktifkan para siswa adalah dengan mengulang materi pelajaran. Tetapi pengulangan materi perlu dilakukan dengan metode dan format yang berbeda agar tidak kebosanan dan ketidakbergairahan belajar bagi peserta didik.

Matematika merupakan salah satu mata pelajaran yang diajarkan di semua jenjang sekolah. Matematika berguna dalam berbagai hal dan berkaitan dengan ilmu pengetahuan. Hal ini sesuai dengan pernyataan Kline yang dikutip oleh Suherman, "Matematika itu bukanlah pengetahuan yang yang dapat sempurna karena dirinya sendiri, tetapi adanya matematika itu terutama untuk membantu manusia agar memahami dan menguasai permasalahan sosial, ekonomi, dan alam. (Suherman, Erman. 2003)

Menurut James yang juga dikutip Suherman "Matematika adalah ilmu tentang logika, mengenal bentuk, susunan, besaran, dan konsep-konsep yang berhubungan satu dengan lainnya dengan jumlah yang banyak dan terbagi dalam 3 (tiga) bidang yaitu : aljabar, analisis dan geometri. (Suherman, Erman. 2003). Jadi, matematika adalah ilmu tentang logika berpikir yang mempelajari bentuk-bentuk, susunan-susunan, besaran, dan konsep-konsep serta satu sama lain saling berhubungan sehingga berguna bagi kehidupan manusia dalam memecahkan permasalahan seharihari maupun dalam pengembangan ilmu-ilmu lainnya.

Pada urain di atas dikatakan bahwa hasil belajar adalah perubahan kebiasaan, pengetahuan, maupun sikap yang ditunjukkan siswa setelah mengalami proses latihan dan interaksi sehingga 
mencapai tingkatan khusus. Jadi hasil belajar matematika adalah perubahan kebiasaan, pengetahuan, maupun sikap yang ditunjukkan siswa setelah mengalami proses kegiatan pembelajaran materi matematika sehingga mencapai tingkatan yang mampu memecahkan permasahan sehari-hari maupun dalam pengembangan ilmu-ilmu lainnya, sesuai jenjangnya yang hasilnya dapat dilihat dari nilai yang diperoleh pada evaluasi dalam bentuk ulangan atau ujian.

Sedangakan hasil belajar matematika pada penelitian ini adalah perubahan kebiasaan, pengetahuan, maupun sikap yang ditunjukkan siswa setelah mengalami proses kegiatan pembelajaran materi barisan aritmatika dan geometri yang hasilnya dapat dilihat dari nilai ulangan harian KD 6.2 yaitu menentukan suku ke-n barisan aritmatika dan barisan geometri.

Pencocokan Kartu Indeks merupakan salah satu cara yang diusung Melvin L. Silberman dalam strategi peninjauan kembali. Ini merupakan cara aktif dan menyenangkan untuk meninjau ulang materi pelajaran. Cara ini memungkinkan siswa untuk berpasangan dan memberi pertanyaan kuis kepada temannya. (Silberman, 2013) Startegi Peninjauan Kembali Dengan Pencocokan Kartu Indeks mengguanakan prosedur berikut :

1). Pada kartu indeks yang terpisah, tulislah pertanyaan tentang apa pun yang diajarkan di kelas. 2). Buatlah kartu pertanyaan dengan jumlah yang sama dengan setengah jumlah siswa. 3). Pada kartu yang terpisah, tulislah jawaban atas pertanyaan-pertanyaan itu. 4). Campurkan dua kumpulan kartu itu dan kocoklah beberapa kali agar benar-benar tercampuraduk. 5). Berikan satu kartu untuk satu siswa. Jelaskan bahwa ini merupakan latihan pencocokan. Sebagian siswa mendapatkan pertanyaan tinjauan dan sebagian lain mendapatkan kartu jawabannya. 6)Perintahkan siswa untuk mencari kartu pasangan mereka. Bila telah terbentuk pasangan, perintahkan siswa yang berpasangan itu untuk mencari tempat duduk bersama. (katakan kepada mereka untuk tidak mengungkapakan kepada pasangan lain apa yang ada di kartu mereka). 7). Bila semua pasangan yang cocok telah duduk bersama, perintahkan tiap pasangan untuk memberikan kuis kepada siswa lain dengan membacakan keras-keras pertanyaan mereka dan menantang siswa lain untuk memberikan jawabannya.

Dari pendapat-pendapat di atas dapat dikatakankan bahwa strategi peninjauan kembali dengan pencocokan kartu indeks pada penelitian ini adalah cara pengulangan materi pelajaran yang merangsang siswa untuk terlibat aktif dalam proses pembelajaran dengan menggunakan kartu indeks yang berisi lembar soal atau jawabannya sehingga siswa memperoleh pasangannya lalu pasangan siswa terlibat aktif dalam kuis pertanyaan.

Dalam menerapkan strategi ini, perlu dialokasikan waktu dalam proses pembelajaran untuk meninjau kembali pemahaman peserta didik pada materi yang telah dipelajari sebelum dilakukan evaluasi dengan cara yang membuat siswa termotivasi untuk aktif dalam pemebelajaran. Strategi peninjauan kembali pemahaman materi dapat dilakukan dengan berbagai cara, antara lain ikhtisar siswa, Teka-Teki Silang dan Pencocokan Kartu Indeks.

Penulis tertarik untuk melakukan penelitian tindakan kelas dengan judul "Penerapan Strategi Peninjauan Kembali Dengan Pencocokan Kartu Indeks dalam Meningkatkan Hasil Belajar Matematika"

\section{METODE PENELITIAN}

Menurut Kemmis dan Mc. Taggart model penelitian tindakan melalui 4 (empat tahap) yaitu perencanaan, tindakan, pengamatan, dan refleksi yang terdiri dari beberapa siklus. Biasanya setelah dilakukan satu siklus akan muncul pemikiran baru sehingga perlu dilakukan perencanaan ulang, tindakan ulang, pengamatan ulang, dan refleksi ulang. Begitulah seterusnya sampai persoalan dianggap teratasi. Tahap-tahap tersebut dapat digambarkan dalam bentuk spiral PTK berikut : 
Vol 1. No. 3, Juli 2021 P-ISSN : 2774-8030, e-ISSN : 2774-8030

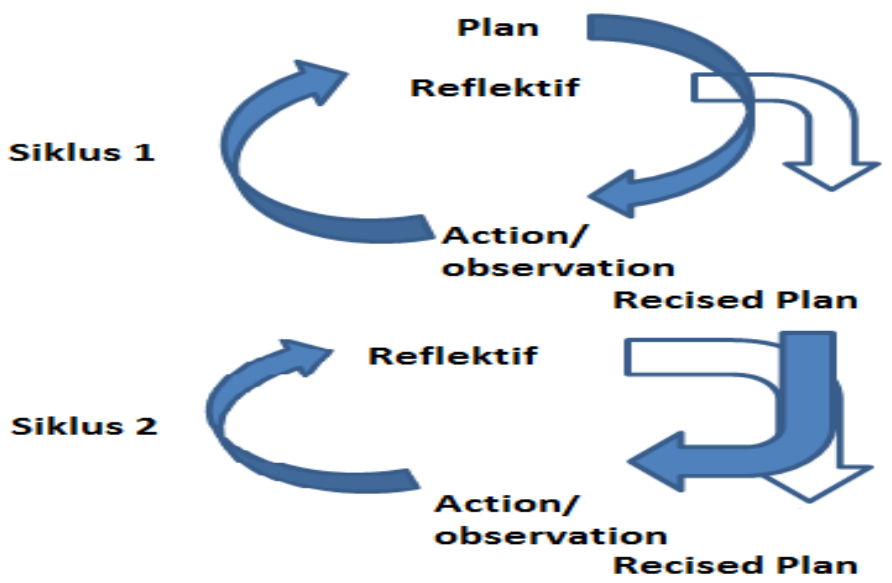

Gambar 1. Spiral PTK (adopsi dari Hopkins, 1992)

Sebelumnya penulis menganalisis data hasil ulangan KD sebelumnya (KD 5.1, 5.2, 5.3 dan 6.1) dari kelas yang diajar sebagai data awal. Setelah itu melakukan tahapan siklus pertama yaitu 1). Perencanaan yang meliputi menganalisis Standar Kompetensi (SK) 6, dan Kompetensi Dasar (KD) 6.2., membuat Rencana Pelaksanaan Pembelajaran (RPP), Membuat Lembar Kerja Siswa, Membuat kartu indeks, Membuat alat evaluasi, Membuat lembar observasi; 2). Pelaksanaan yang meliputi Memberi penjelasan teknis dan alur pembelajaran siklus pertama untuk tiap pertemuan, Menyajikan materi pelajaran pertemuan pertama dan kedua, Melaksanakan peninjauan kembabali dengan pencocokan kartu indeks pada pertemuan ketiga sesuai prosedur, Kolaborator melakukan observasi terhadap aktivitas siswa dan kegiatan guru., Melakukan evaluasi hasil belajar berupa ulangan harian; 3) Pengamatan teradap Aktivitas atau partisipasi siswa selama pembelajaran, Kemampuan siswa menyelesaikan soal pada kartu indeks , Kemampuan siswa dalam menjawab pertanyaan kuis, Ketepatan waktu dalam menjawab pertanyaan; 4) Refleksi : Mengenai keberhasilan dalam penelitian ini diperlihatkan oleh rata-rata nilai ulangan harian $\geq 73$ dan ketuntasan belajar $\geq 70 \%$.

Pada siklus kedua, Peneliti membuat perencanaan tindakan berdasarkan hasil refleksi pada siklus pertama dengan strategi yang sama yaitu peninjauan kembali dengan pencocokan kartu indeks seperti pada siklus pertama, tetapi dimungkinkan diberikan perlakuan-perlakuan khusus berdasarkan hasil refleksi siklus pertama. Pengamatan dilakukan lebih tajam terhadap partisipasi siswa dalam pembelajaran dengan memperhatikan hasil refleksi pada siklus pertama. Sebagai refleksi, Keberhasilan dalam penelitian ini diperlihatkan oleh rata-rata nilai ulangan harian $\geq 73$ dan ketuntasan belajar $\geq 70 \%$.

\section{HASIL DAN PEMBAHASAN}

\section{1) Hasil Penelitian}

Siklus pertama dilaksanakan sesuai dengan rencana, yaitu 4 (empat) kali pertemuan pertemuan yaitu tanggal 6, 10, 12 dan 13 Februari 2014. Pada pertemuan ke-1 jumlah siswa yang hadir 30 orang ( 3 orang tidak hadir), pada pertemuan kedua siswa yang hadir 33 orang (100\% hadir), pada pertemuan ke-3 hadir 32 orang (1 orang tidak hadir) serta satu orang observer /kolaborator sedangkan pada pertemuan ke-4 hadir 32 orang (1 orang tidak hadir).

Aspek aktifitas siswa yang diamati selama proses pembelajaran berlangsung meliputi mendapatkan pasangan sesuai kartu indeks, mengajukan pertanyaan kuis, dan menjawab pertanyaan kuis. Rekapitulasi hasil pengamatan ditunjukkan pada tabel berikut : 
Vol 1. No. 3, Juli 2021 P-ISSN : 2774-8030, e-ISSN : 2774-8030

Tabel 3. Rekapitulasi Aktivitas Siswa Pada Peninjauan Kembali Dengan Pencocokan Kartu Indeks pada Siklus 1

\begin{tabular}{|l|c|c|}
\hline Indikator Aktivitas & Jumlah Pasangan & Prosentase \\
\hline $\begin{array}{l}\text { Mendapatkan Pasangan sesuai kartu } \\
\text { indeks }\end{array}$ & 15 & $93,75 \%$ \\
\hline Mengajukan Pertanyaan Kuis & 9 & $56,25 \%$ \\
\hline Menjawab pertanyaan kuis & 9 & $56,25 \%$ \\
\hline & Rata-rata & $68,75 \%$ \\
\hline
\end{tabular}

Sedangkan rekapitulasi hasil ulangan harian pada siklus pertama ditunjukkan oleh tabel berikut :

Tabel 4. Hasil Ulangan Harian Siklus 1

\begin{tabular}{|c|c|}
\hline Nilai & Banyak Siswa \\
\hline $52-58$ & 6 \\
\hline $59-65$ & 0 \\
\hline $66-72$ & 5 \\
\hline $73-79$ & 13 \\
\hline $80-86$ & 1 \\
\hline $87-93$ & 2 \\
\hline $94-100$ & 33 \\
\hline Banyak siswa yang mengikuti ulangan & 75,64 \\
\hline Rata-rata & 21 \\
\hline Banyak siswa yang tuntas & $63,64 \%$ \\
\hline Ketuntasan Belajar (KTB) & 100 \\
\hline Nilai tertinggi & 58 \\
\hline Nilai terendah & 6 \\
\hline
\end{tabular}

Tabel 3 menunjukkan bahwa tingkat aktifitas siswa dalam proses pembelajaran adalah $68,75 \%$. Pada tabel 4 memperlihatkan hasil belajar matematika yang diikuti oleh seluruh siswa kelas IX.2, memperlihatkan nilai rata-rata adalh 75,64, nilai tertinggi adalah 100, nilai terendah adalah 58 serta siswa yang tuntas adalah 21 orang dari 33 siswa $(63,64 \%)$

Berdasarkan data proses dan hasil belajar pada siklus ini, terdapat temuan-temuan sebagai berikut : 1). Tingkat aktivitas siswa masih belum optimal $(68,75 \%)$, terutama pada pengajuan pertanyaan dan menjawab pertanyaan. 2). Nilai rata-rata cukup baik, sedikit di atas KKM yang ditetapkan. 3). Ketuntasan belajar hanya mencapai 63,64\%, masih belum mencapai angka prosentase yang diharapkan yaitu $\geq 70 \%$ 4). Hasil tanya jawab dengan siswa, menggambarkan strategi peninjauan kembali dengan pencocokan kartu indeks menyenangkan bagi siswa.

Pada siklus kedua pertemuan ke-1, jumlah siswa yang hadir 33 orang (100\% hadir), pada pertemuan kedua siswa yang hadir 33 orang (100\%), dan pada pertemuan ke-3 hadir 32 orang (1 orang Izin untuk mengikuti lomba olah raga).

Seperti pada siklus pertama aspek aktifitas siswa yang diamati selama proses pembelajaran berlangsung meliputi mendapatkan pasangan sesuai kartu indeks, mengajukan pertanyaan kuis, dan menjawab pertanyaan kuis. Rekapitulasi hasil pengamatan ditunjukkan pada tabel berikut : 
Vol 1. No. 3, Juli 2021 P-ISSN : 2774-8030, e-ISSN : 2774-8030

Tabel 5. Rekapitulasi Aktivitas Siswa Pada Peninjauan Kembali Dengan Pencocokan Kartu Indeks pada Siklus 2

\begin{tabular}{|l|c|c|}
\hline Indikator Aktivitas & Jumlah Pasangan & Prosentase \\
\hline $\begin{array}{l}\text { Mendapatkan Pasangan sesuai kartu } \\
\text { indeks }\end{array}$ & 17 & $100 \%$ \\
\hline Mengajukan Pertanyaan Kuis & 13 & $76,47 \%$ \\
\hline Menjawab pertanyaan kuis & 15 & $88,24 \%$ \\
\hline & Rata-rata & $88,24 \%$ \\
\hline
\end{tabular}

Sedangkan rekapitulasi hasil ulangan harian pada siklus pertama ditunjukkan oleh tabel berikut :

Tabel 6. Hasil Ulangan Harian Siklus 2

\begin{tabular}{|l|c|}
\hline Nilai & Banyak Siswa \\
\hline $52-58$ & 1 \\
\hline $59-65$ & 3 \\
\hline $66-72$ & 14 \\
\hline $73-79$ & 7 \\
\hline $80-86$ & 1 \\
\hline $87-93$ & 2 \\
\hline $94-100$ & 32 \\
\hline Banyak siswa yang mengikuti ulangan & 79,19 \\
\hline Rata-rata & 24 \\
\hline Banyak siswa yang tuntas & $75,00 \%$ \\
\hline Ketuntasan Belajar (KTB) & 100 \\
\hline Nilai tertinggi & 57 \\
\hline Nilai terendah & 4 \\
\hline
\end{tabular}

Tabel 5 menunjukkan bahwa tingkat aktifitas siswa dalam proses pembelajaran adalah 88,24\%. Sedangkan tabel 6 memperlihatkan hasil belajar matematika pada siklus kedua yang diikuti oleh 32 siswa kelas IX.2 (1 orang tidak hadir), memperlihatkan nilai rata-rata adalah 79,19, nilai tertinggi adalah 100, nilai terendah adalah 57. Sedangkan banyak siswa yang tuntas adalah 24 orang dari 34 siswa yang mengikuti ulangan harian. Ini berarti ketuntasan belajar adalah 75,00 \% . Sebagai refleksi, berdasarkan data proses dan hasil belajar pada siklus kedua ini, terdapat temuan, Tingkat aktivitas siswa tinggi yaitu 88,24\%., Nilai rata-rata ulangan mencapai 79,19 dan mengalami peningkatan dari rata-rata ulangan pada siklus I serta berada di atas KKM yang ditetapkan yaitu 73,00, Ketuntasan belajar mencapai 75,00\%, dan telah melampaui angka prosentase yang diharapkan yaitu $\geq 70 \%$, Hasil tanya jawab dengan siswa, menggambarkan strategi peninjauan kembali dengan pencocokan kartu indeks menyenangkan bagi siswa.

\section{2) Pembahasan}

Sebagaimana diuraikan pada latar belakang penelitian ini, bahwa hasil belajar siswa kelas IX.2 dalam pelajaran matematika sangat rendah. Rata-rata ualangan harian pada kompetensi dasar sebelumnya adalah 58,97 dengan ketuntasan belajar (KTB) 23,51\%. Hal ini disebabkan: 1). Matematika dianggap sebagai mata pelajaran yang menjadi momok dan sulit dipahami oleh sebagian besar siswa; 2). Proses pembelajaran yang kurang menyenangkan; 3). Kemampuan siswa 
untuk bertanya rendah, karena siswa tidak memahami konsep yang sedang dibahas sehingga ia tidak tahu apa yang harus ditanyakan atau alasan takut/malu dengan guru; 4). Motivasi siswa untuk mengulang materi pelajaran kurang.

Penerapan strategi peninjauan kembali dengan pencocokan kartu indeks merupakan salah satu solusi dalam mengatasi rendahnya hasil belajar siswa sebagaimana diuraikan di atas. Tindakan ini diterapkan selama dua siklus terhadap siswa kelas IX.2 SMP Negeri 2 Jakarta. Hasil pengamatan aktivitas siswa dalam pembelajaran tinggi. Hal ini mengakibatkan meningkatnya hasil belajar matematika.

Resume data hasil penelitian tindakan kelas dari sebelum PTK, hingga siklus pertama dan kedua, terlihat pada tabel berikut ini :

Tabel 7. Hasil Belajar Matematika Siswa Kelas IX.2 SMPN 2 Jakarta Semester 2 Tahun Pelajaran 2013/2014

\begin{tabular}{|c|c|c|c|c|c|}
\hline & $\begin{array}{c}\text { Rata-rata } \\
\text { Ulangan }\end{array}$ & Peningkatan & $\begin{array}{c}\text { Ketuntasan } \\
\text { Belajar }\end{array}$ & Peningkatan & $\begin{array}{c}\text { Analisis } \\
\text { Keberhasilan }\end{array}$ \\
\hline $\begin{array}{c}\text { Sebelum } \\
\text { PTK }\end{array}$ & $\mathbf{5 8 , 9 7}$ & & $\mathbf{2 3 , 5 1 \%}$ & & \\
\hline Siklus I & 75,64 & 16,67 & $\mathbf{6 3 , 6 4 \%}$ & $\mathbf{4 0 , 1 3 \%}$ & Kurang Berhasil \\
\hline Siklus II & 79,19 & 3,55 & $75,00 \%$ & $11,36 \%$ & Berhasil \\
\hline $\begin{array}{c}\text { Indikator } \\
\text { Keberhasil } \\
\text { an }\end{array}$ & 73,00 & $70 \%$ & & \\
\hline
\end{tabular}

Data di atas menunjukkan bahwa dari sebelum PTK rata-rata ulangan harian matematika dari beberapa KD adalah 58,97 sedangkan pada siklus pertama adalah 75,64, terjadi peningkatan sebesar 16,67 poin . Sedangkan Ketuntasan Belajar dari 23,51\% sebelum PTK menjadi 63,64\% pada siklus pertama, terjadi peningkatan sebesar 40,13\%. Pada siklus pertama nilai rata-rata ulangan sudah melewati indikator keberhasilan $(\bar{x} \geq 73,00)$, tetapi Ketuntasan Belajar belum mencapai indikator keberhasilan $(\mathrm{KTB} \geq 70 \%)$. Jadi pada siklus pertama strategi peninjauan kembali dengan pencocokan kartu indeks belum berhasil karena belum mencapai kriteria keberhasilan PTK $((\bar{x} \geq 73,00$ dan KTB $\geq 70 \%)$.

Dari siklus pertama ke siklus kedua rata-rata ulangan harian meningkat dari 75,64 menjadi 79,19 , terjadi peningkatan sebesar 3,55 poin, sedangkan ketuntasan belajar dari $63,64 \%$ menjadi $75,00 \%$, terjadi peningkatan sebasar $11,36 \%$. Pada siklus kedua nilai rata-rata ulangan sudah melewati indikator keberhasilan $(\bar{x} \geq 73,00)$, dan Ketuntasan Belajar juga telah melewati indikator keberhasilan (KTB $\geq 70 \%$ ). Jadi pada siklus kedua strategi peninjauan kembali dengan pencocokan kartu indeks berhasil meningkatkan hasil belajar, karena melewati kriteria keberhasilan PTK $(\bar{x} \geq$ 73,00 dan KTB $\geq 70 \%$ ).

Pada siklus kedua siswa yang aktif bertanya dan menjawab diberi stimulus yaitu : 1). berupa poin untuk menambah nilai. 2). yang memberikan pertanyaan diarahkan untuk menunjuk langsung pasangan siswa apabila tidak ada pasangan yang mengacungkan tangan untuk menjawabnya. Hal ini berakibat seluruh siswa berusaha menyelesaikan soal yang diajukan karena ada kemungkinan ditunjuk.

Hasil ini, sejalan dengan yang disampaikan oleh Silberman (2013) bahwa salah satu cara yang pasti untuk membuat pembelajaran tetap melekat dalam pikiran adalah dengan mengalokasikan waktu untuk meninjau kembali apa yang telah dipelajari. Materi yang telah dipelajari oleh siswa cenderung lima kali lebih melekat di dalam pikiran ketimbang yang tidak 
dibahas kembali. Itu karena pembahasan kembali memungkinkan siswa untuk memikirkan kembali informasi tersebut dan menemukan cara untuk menyimpannya di dalam otak.

Siti Aisah (2014) dalam penelitiannya berhasil meningkatkan ketuntasan belajar siswa berturut-turut dari $71 \%$ pada siklus I, menjadi $81,53 \%$ pada II, dan menjadi $100 \%$ pada siklus III

Siti Muzkiyah (2018) dalam penelitiannya berhasil meningkatkan aktivitas siswa dari $54,99 \%$ pada siklus pertama menjadi $73,93 \%$ pada siklus kedua dan meningkatkan hasil belajar dari 61,78 pada siklus pertama menjadi 67,50 pada siklus kedua.

Satria Wibowo, Adguna (2018) dalam penelitiannya berhasil meningkatkan keaktifan siswa kelas XI TAV A SMK Negeri 2 Klaten dari 54,3\% pada siklus pertama menjadi $64,8 \%$ pada siklus kedua dan meningkatkan hasil belajar dari 59,38 pada siklus pertama menjadi 75,13 pada siklus kedua.

Penelitian serupa juga dilakukan oleh Muhammad Istiqlal (2018). Dalam penelitiannya berhasil meningkatkan keaktifan siswa kelas XI TAV A SMK Negeri 2 Klaten dari 79,56\% pada siklus pertama menjadi $86,11 \%$ pada siklus kedua dan meningkatkan hasil belajar dari 59,38 pada siklus pertama menjadi 75,13 pada siklus kedua.

\section{KESIMPULAN}

Berdasarkan hasil penelitian dan pembahasan terhadap data penelitian tindakan kelas ini, rata-rata hasil belajar siswa kelas IX.2 sebelum PTK adalah 58,97\%. Pada siklus I dan II berturutturut mencapai $75,64 \%$ dan 79,19\%. Sedangkan ketuntasan belajar sebelum PTK, pada siklus I dan siklus II berturut-turut perolehannya adalah $23,51 \%, 63,64 \%$ dan $75,00 \%$.

Keberhasilan ini sesuai sejalan dengan yang disampaikan oleh Silberman (2013) bahwa salah satu cara yang pasti untuk membuat pembelajaran tetap melekat dalam pikiran adalah dengan mengalokasikan waktu untuk meninjau kembali apa yang telah dipelajari. Selain itu penelitian yang dilakukan oleh Siti Aisah (2014), Siti Muzkiyah (2018), Adguna Satria Wibowo (2018), dan Muhammad Istiqlal (2018) juga membuktikan bahwa Strategi Peninjauan Kembali dengan kartu Indeks dapat meningkatkan aktivitas siswa, meningkatkan ketuntasan belajar siswa, dan/atau meningkatkan hasil belajar siswa.

Jadi dapat disimpulkan bahwa penerapan strategi peninjauan kembali dengan pencocokan kartu indeks berhasil meningkatkan hasil belajar matematika pada siswa kelas IX.2 SMPN 2 Jakarta. Penulis menyarankan kepada rekan-rekan guru untuk mencoba menggunakan strategi peninjauan kembali dengan pencocokan kartu indeks pada materi atau mata pelajaran lainnya

\section{DAFTAR PUSTAKA}

Aisah, Siti. (2014). Pembelajaran Aktif Model Pencocokan Kartu Indeks dalam Membantu Penguasaan Materi Pelajaran Matematika pada Siswa Kelas IX.F Semester gasal MTs Negeri Kota Madiun Tahun pelajaran 2014-2015

Biro Hukum dan Organisasi Kementerian Pendidikan Nasional. (2008). Peraturan Menteri Pendidikan Nasional Nomor 20 Tahun 2007 tentang Estándar Penilaian. Jakarta.

Biro Hukum dan Organisasi Kementerian Pendidikan dan Kebudayaan. (2013). Peraturan Mentereri Pendidikan dan Kebudayaan Nomor 54 Tahun 2013 tentang Standar Kompetensi Lulusan Pendidikan Dasar dan Menengah, Jakarta.

Biro Hukum dan Organisasi Kementerian Pendidikan dan Kebudayaan. (2013). Peraturan Menteri Pendidikan dan Kebudayaan Nomor 65 Tahun 2013 tentang Standar Proses. Jakarta. Isnawati, Nurlaela. (2010). “Guru Positif-Motivatif”. Laksana. Jogjakarta.

Istiqlal, Muhammad. 2018, Pola Penerapan Metode Co-op Co-op dan Strategi Peninjauan Kembali dalam Pembelajaran Matematika untuk Meningkatkan Keaktifan dan Kreativitas Siswa, 
https://www.google.com/url?sa=t\&source=web\&rct=j\&url=https://jurnal.iainambon.ac .id/index.php/INT/article/download/445/357\&ved=2ahUKEwjaiLOp8bzyAhWJUn0K HYeRB7IQFnoECAwQAQ\&usg=AOvVaw0pqtIAdSBHuUy-yFGen2h\&cshid $=1629369562147$

Kemendiknas. 2002. Kamus Bahasa Indonesia. Edisi ke - 3. Cetakan kedua. Jakarta : Balai

Pustaka.

Kunandar. 2007. Guru Profesional; Implementasi Kurikulum Tingkat Satuan Pendidikan (KTSP) dan Sukses Dalam Sertifikasi Guru. Jakarta : Rajagrafindo Persada.

Kunandar. (2008). Langkah Mudah Penelitian Tindakan Kelas sebgai Pengembangan Profesi Guru, Jakarta : Rajawali Pers.

Muzkiyah, Siti. (2018). Penerapan Strategi Index Card Math untuk Meningkatkan Aktivitas dan Hasil Belajar Siswa pada Mata Pelajaran PPKn Kelas IV SDN 1 Balekencono Batanghari LampungTimur,

https://www.google.com/url?sa=t\&source=web\&rct=j\&url=https://repository.metrouniv .ac.id/id/eprint/2081/1/SKRIPSI\%2520SITI\%2520MUZKIYAH\%2520NPM.\%252013 105845.pdf\&ved=2ahUKEwjaiLOp8bzyAhWJUn0KHYeRB7IQFnoECAQQAQ\&usg= AOvVaw3oRRHbdlupFzDd4_qBtDAt

Satria Wibowo, Adguna. (2018). Penerapan Model Pembelajaran Kooperatif Index Card Math dalam Meningkatkan Keaktifan dan Hasil belajar Siswa pada Mata Pelajaran Perekayasaan Sistem Antena di Kelas XIA SMA negeri 2 Klaten https://www.google.com/url?sa=t\&source=web\&rct=j\&url=http://eprints.uny.ac.id/592 02/1/Skripsi_Adiguna\%2520Satrya\%2520Wibowo_13502244003.pdf\&ved=2ahUKE wjaiLOp8bzyAhWJUn0KHYeRB7IQFnoECB0QAQ\&usg=AOvVaw0iXe3oFuXlJVk NgCngD-c7

Silberman, L. Melvin. (2013). Active Learning 101 Cara Belajar Siswa Aktif (Cetakan VIII). Bandung. Nuansa Cendekia.

Suherman E. dkk.. (2003). Strategi Pembelajaran matematika Kontenporer. Jurusan Matematika FPMIPA, UPI. Bandung. 